Original Research Paper

\title{
Genetic Diversity in Merozoite Surface Protein.1 of Plasmodium falciparum in Highlands: Wamena Papua Indonesia
}

\author{
${ }^{1}$ Rosye Hefmi Rechnelty Tanjung, ${ }^{2}$ Yulius Sarungu, ${ }^{3}$ Meidy Johana Imbiri, ${ }^{3}$ Ade Irma Resmol, \\ ${ }^{1}$ Dirk Yanes Persius Runtuboi and ${ }^{1}$ Joko Suyono \\ ${ }^{1}$ Department of Biology, Cenderawasih University, Papua Province, Indonesia \\ ${ }^{2}$ Department of Public Health, Cenderawasih University, Papua Province, Indonesia \\ ${ }^{3}$ Institute of Health Science Jayapura, Indonesia
}

Article history

Received: 11-10-2018

Revised: $10-12-2018$

Accepted: 8-01-2019

Corresponding Author: Dirk Yanes Persius Runtuboi, Department of Biologi Cenderawasih University Indonesia Email: diki_runtuboi@yahoo.com

\section{Introduction}

Malaria is one of social health problems in the world. This disease influences the high death rate of pregnant women, babies and children under the ages of 5 years old (Permenkes Malaria, 2009). Every year there are about 500 million people infected malaria and more than 1 million people die (Ernawati et al., 2011). High cases of malaria parasite happen in some countries in Africa and Asia, including Indonesia. In Indonesia, until 2009, 80\% re- agencies/municipalities were regarded as malaria endemic, about $45 \%$ people who lived in endemic areas are at risk to being infected with malaria parasite. There are 1.143.023 cases reported in 2009 (Harliani and Nurhadi, 2015). This number of cases were maybe not the exact number of cases due to the fact that endemic

\begin{abstract}
Malaria is the first killer as well as endemic disease in highland, lowland and coastal areas of Papua. In 2016 there were 160 thousands cases noted and $80 \%$ of the cases were caused by Plasmodium falciparum. Total sample for this study were provided by a clinical trial conducted from May to June 2018 in the regional hospital of Puncak Jaya, Wamena, located in the highland region of Papua. Positive blood samples was collected in a ethylene diaminetetra Genomic DNA Mini Kit (Blood/Cultured Cell). The primary reactions used a set of primer corresponding to the conserved regions of block 2 of $m s p 1$. The second reactions primer set targets specific allelic families of $m s p 1$ (K1, MAD20 and RO33). All polymerase chain reaction amplicons were analyzed by electrophoresis in a $1.0 \%$ agarose gel. A total of 26 bood samples of positive $P$. falciparum were analyzed, 24 (93.2\%) were predominant with $20.8 \%(8 / 24)$, followed by the RO33 allelic family with $8.2 \%(2 / 24)$ and the K1 allelic family with $1 / 24(4.2 \%)$. The frequency of single allele is 11/24 (45.8\%) while multi-allele are 16/24 (66.7\%) with K1/RO33, MAD20/RO33, K1/MAD20/RO33 respectively $2 / 24(8.3 \%), 8 / 24(33.3 \%)$ and $6 / 24(25 \%)$.
\end{abstract}

Keywords: Plasmodium falciparum, MSP-1, Malaria, Highland Papua malaria cases in remote villages were not easily reached by transportation and low health services.

Of half Indonesian population, about 90 millions people live in endemic area of malaria (Bapenas, 2005). It is predicted that there are about 30 million cases every year and only $10 \%$ are well treated and have health facilities (Bapenas, 2005). Papua is a province in Indonesia that has the highest malaria case. Data from Provincial Health Department showed 294 cases in 2016, lower than previous cases in 2015 where only 497 thousands cases reported and this number is still regarded high (Papua, 2017). The most dominant causes of malaria parasite is Plasmodium falciparum (80\%) (Papua, 2017).

Genotyping of malaria parasite population is an important tool to determine the types and number of parasitic clone in a falciparum malarial infection. The most widely used techniques for genotyping malaria 
infection is based on amplification of the polymorphic gene encoding Merozoite Surface Protein (MSP) (Hoffmann et al., 2003; Kang et al., 2010; Sorontou and Pakpahan, 2015; Muhammed et al., 2015; Some et al., 2018). The MSP1 gene of $P$. falciparum is a potential malaria vaccine candidate. The protein of the MSP1 gene is associated with the protection of the parasite (Sorontou and Pakpahan, 2015).

Gene $M S P 1$ is the most conserved gene fragment that can be used as genetic marker to identify $P$. falciparum. The size of $M S P 1$ is about $19 \mathrm{kDa}$ and this protein has important role in erythrocyte invasion. Gene $M S P 1$ is located in chromosome 9 and contains of 17 blocks of sequences flanked by conserved region. Block 2 is the most polymorphic part and grouped into three allelic families namely MAD20, K1 and RO33 (Some et al., 2018). This study aimed to establish genetic polymorphism of MAD20, K1 and RO33allelic types of the mspl gene among $P$. falciparum clinic isolates from the regional hospital of Puncak Jaya, Wamena Papua.

\section{Materials and Methods}

All subjects aged 12 years or more attending the regional hospital of Puncak Jaya, Wamena Papua with fever or history of fever in the last $24 \mathrm{~h}$ were referred by a clinician for screening of malarial infection by using Giemsa-stained thick and thin blood smears. Written informed consent was obtained for all donors and $3 \mathrm{ml}$ venous blood sample in EDTA tube that contain anticoagulant was taken from 26 P. falciparum infected individuals. All $P$. falciparum malaria patients who enrolled in this study met the following criteria (i) they presented symptoms, (ii) their thick blood smears contained only $P$. falciparum, (iii) $P$. falciparum infection at parasites densities $>10000$ parasites/ $\mu$ l) (iv) they did not use chemoprophylaxis and had not taken anti-malarial drugs (self-treatment) (v) if female, they were neither pregnant nor breast feeding and (vi) their blood was collected on the day of diagnosis before initiating of malaria treatment. After the collection of the blood samples, the patients were immediately treated according to Indonesian Ministry of Health standards for malaria therapy (Ricio et al., 2013; Some et al., 2018).
Blood samples in EDTA tubes was then sent to Medical Laboratory of Genetic Science of PT. Genetika Science Indonesia for DNA extraction in Jakarta. DNA extraction was carried out using method of Geneaid Genomic DNA Mini Kit (Blood/Cultured Cell). PCR Amplifications were perform using KOD FX Neo (Toyobo). The primary and nested (second amplifications) PCR reactions were carried out $50 \mu \mathrm{L}$ reaction volume using $5 \mu \mathrm{L}$ of template DNA and $1 \mu \mathrm{L}$ primary PCR product respectively in two reactions. The allelic family-specific primer were used in the nested reaction for block2 of $m s p 1$ corresponding to MAD20, K1 and RO33 allelic families. The primer is used as follows:

\section{Results}

P. falciparum parasites were detected in a total of 26 samples by using Giemsa-stained thick and thin blood smears based on microscopic diagnostic. PCR genotyping was done for 26 selected parasitaemia positive sample. PCR amplification was successful for MSP1 in $92.3 \%(24 / 26)$ of the samples.

This study also identified polymorphism of allelic families of $M S P-1$, namely $\mathrm{K} 1$, MAD20, RO33 and combination of three alleles. In $M S P-1$, the MAD20 allelic family was predominant with $20,8 \%(8 / 24)$, followed by the RO33 allelic family with $8.2 \%(2 / 24)$ and the K1 allelic family with $4.2 \% \quad(1 / 24)$. The frequency of single allele is $11 / 24(45.8 \%)$ while multiallele are 16/24 (66.7\%) with K1/RO33, MAD20/RO33, K1/MAD20/RO33 respectively 2/24 (8.3\%), 8/24 $(33.3 \%)$ and $6 / 24(25 \%)$. This study did not find multiallele with K1/MAD20.

\section{Discussion}

Genetic diversity of Merozoite Surface Protein are currently being recommended in antimalarial clinical trials as standard markers to distinguish recrudescent from newly infecting malaria parasites (WHO, 2007; Some et al., 2018). However, very few studies have investigated the genetic diversity of merozoite surface protein in malaria parasites circulating in many endemic country including Indonesia especially in Papua.

Table 1: Primer Arrangement that is used for amplification $M S P-1$

\begin{tabular}{lll}
\hline Locus & Primer & Nucleotide Arrangement \\
\hline $\begin{array}{l}\text { Reaction PCR I } \\
\text { Primer }\end{array}$ & $m s p 1$ & CTAGAAGCTTTAGAAGATGCAGTATTG \\
$\begin{array}{l}\text { Reaction PCR II } \\
m s p 1\end{array}$ & & CTTAAATAGTATTCTAATTCAAGTGGATCA \\
& K1-MAD20 & AAATGAAGAAGAAATTACTACAAAAGGTGC \\
& & GCTTGCATCAGCTGGAGGGCTTGCACCAGA \\
& AAATGAAGGAACAAGTGGAACAGCTGTTAC \\
& ATCTGAAGGATTTGTACGTCTTGAATTACC \\
& RO33 & CAAAGGATGGAGCAAATACTCAATTGTTG \\
& &
\end{tabular}



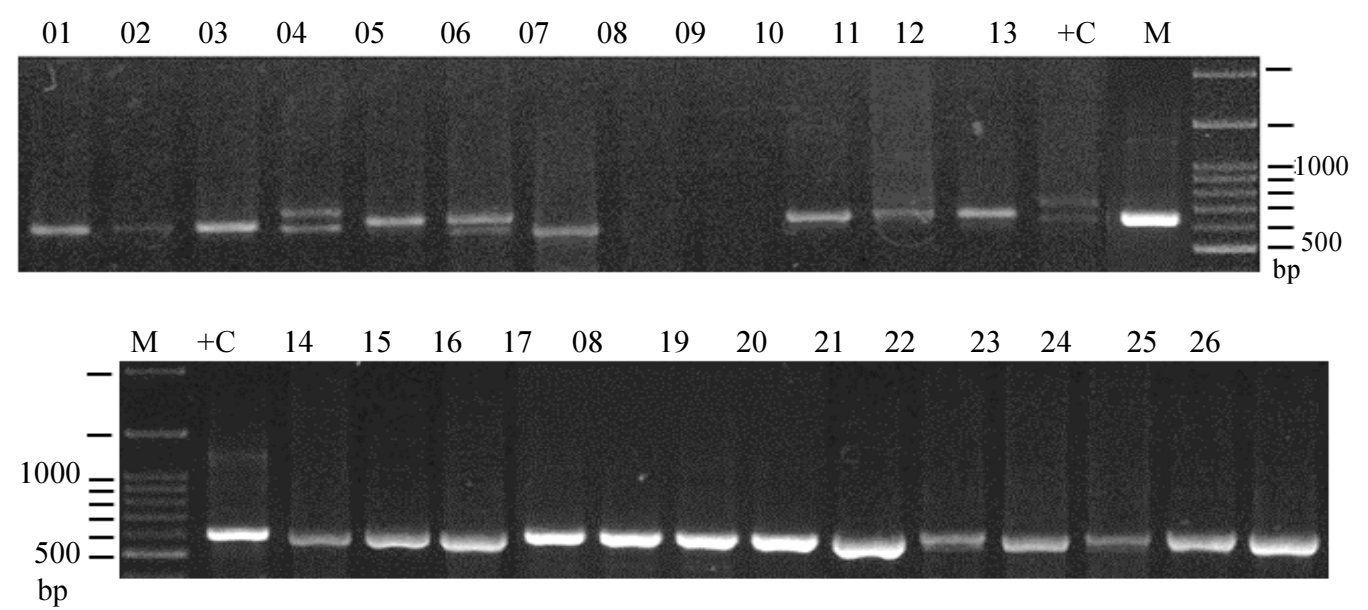

Fig. 1: Electrophoregram of MSPI PCR products of $P$. falciparum. Lanes 01-07, 10-26 shows pattern of PCR fragments in genetic marker display by these isolates. Lanes 08,09 showed no presence of DNA fragmen. $+\mathrm{C}=$ positive control, $\mathrm{M}=\mathrm{Marker}(100 \mathrm{bp})$

This is the first study that gives information about genetic diversity of Merozoite Surface Protein.1 of $P$. falciparum in the highland region of Wamena, Papua. According to Kolawole et al. (2016) merozoite Surface Protein 1 of $P$. falciparum is a major surface protein. The protein is a principal target of human immune response and is a promising candidate for a blood stage sub unit vaccine. Thus, Some et al. (2018) also highlighted that genotyping of malaria parasite population remain an important tool to determine the types and number of parasites clones in an infections.

Our study showed that PCR typing of MSP-1 (block 2) of $P$. falciparum in Puncak Jaya Wamena Papua have a highly complex genetic diversity. All third types of $m s p 1$ allelic families MAD20, RO33 and $\mathrm{K} 1$, were identified. Our further study of $M S P 1$ allelic families MAD20, RO33 and K1 showed high recombination. From 24 isolate sample of gene $M S P 1$ found is polyallele MAD20/RO33 (33,3\%) (Fig. 1). In contrast with previous study in Brazil, Myamnar, Thailand and West Sumatera, where the highest frequency is mono allele (Atroosh et al., 2011; Kolawole et al., 2016; Khaminsou et al., 2011; Oyebola et al., 2014; Mohammed et al., 2015). According to Oyebola et al. (2014) areas with high malaria spread generally have high parasite diversity with multi allele or polyclonal character.

Recombinatios of $m s p 1$ allelic families MAD20, RO33 and K1 in the study in contrast with Sorontou and Pakpahan's report (2015) in lowlands and coastal areas of Papua (Koya \& Skouw). In this study, variation of poly allele K1/MAD20 was not detected.

Various genes of $P$. falciparum were expressed as surface protein, especially $M S P 1$ is a form of genetic diversity that exist in a population. Geographically, different locations also influence genetic diversity. This is due to some cases, two of them are mutation and recombination (Nurwidayati, 2010).

\section{Conclusion}

Genetic polymorphism with various allele types can be identified in $M S P-1$ block $2 P$. falciparum that include $\mathrm{K} 1, \mathrm{MAD} 20$ and RO33.

This study result showed that the highest frequency of infection was caused by polyclonal (poly allele) i.e. MAD20/RO33, while the highest frequency of monoclonal infection (mono allele) is MAD20. This study did not find combination of variation allele K1/MAD20.

\section{Acknowledgement}

We would like to express our gratitude to Mr. Felly G Sahureka, Dr. M. Kes., Sp. PK the Head of Hospital and staffs of Laboratory of Regional Hospital of Puncak Jaya Regency who have helped the researchers during sample collection. Our thanks also goes to Mr. Hamid and staff of Health Laboratory of Provincial Health Laboratory who have helped us storing the samples. We also thank the Laboratory of Genetic Science who have helped the analysis process of biomolecular. All research was funded by the Ministry of Research, Technology and Higher Education Indonesia.

\section{Author's Contributions}

Rosye H.R.Tanjung: Fully involved in all phases of the study, including in laboratory during molecular Analysis, data analysis, interpretation and write-up of the manuscript.

D.Y.P Runtuboi: Designed the study project critical revised the manuscript. Fully involved in all phases of the study including in laboratory during molecular Analysis, data analysis, interpretation, and write-up of the manuscript. 
Y. Sarungu: Involved in statistical analysis of data and critical revision of manuscript for publication.

M.J Imbiri and A.I Resmol: Contributed to write up, read and approved the final manuscript.

J. Suyono: Contributed to interpretations molecular data, write up, read and approved the final manuscript.

\section{Competing Interest}

The authors declare that they have no competing interests.

\section{Ethics}

The aims and objectives of the study was discussed with Head of the hospital and staffs of regional Hospital Laboratory of Puncak Jaya Regency. Ethical clearance of Ethics Committee and permission to undertake the study were obtained from these stakeholders. Each study participant after being briefed and offered the opportunity to ask questions about the study, was provided with individual informed written consent form to sign or thumb print. The written consent forms and participant information form were kept separately from the data collections tools.

\section{References}

Atroosh, W.M., H.M. Al-Mekhlafi, M.A.K. Mahdy, R. Saif-Ali and A.M. Al-Mekhlafi et al., 2011. Genetic diversity of Plasmodium falciparum isolates from Pahang, Malaysia based on MSP-1 and MSP-2 genes. Parasit Vectors, 4: 1-9.

DOI: $10.1186 / 1756-3305-4-233$.

Bapenas, 2005. Summary of reports on progress towards achieving. Indonesia's Millennium Development Goals. pp: 24-26.

Ernawati, K., B. Soesilo, A. Duarsa and Rifqatussa'adah, 2011. Individual and Housing Environment Risk Factors Related to Malaria in Punduh Pedada, Pesawaran District of Lampung Province in 2010. Makara Kesehatan, 15: 51-57.

Harliani, N.M. and Nurhadi, 2015. Factors Related to Malaria Incidence in the Working Area of Pangkep District Kalmas Liukang Health Center. J. Ilmiah Kesehatan Diagnosis, 6: 749-746.

Hoffmann, E.H.E., P.E.M. Ribola and M.U. Ferreira, 2013. Genetics relatedness of Plasmodium falciparum isolates and the origin of allelic diversity at the merozoites surface protein -1 $(M S P-1)$ locus in Brazil and Vietnam. Malaria J.

Kang, J.M., S.U. Moon, J.Y. Kim, S.H. Cho and K. Lin et al., 2010. Genetic polymorphism of merozoite surface protein-1 and merozoite surface protein-2 in Plasmodium falciparum field isolates from Myanmar. Malaria J. DOI: 10.1186/1475-2875-9-131
Khaminsou, N., O. Kritpetcharat, J. Daduang, L. Chaererntanyarak and P. Kritpetcharat, 2011. Genetic analysis of the merozoite surface protein-1 block 2 allelic types in Plasmodium falciparum clinical isolates from Lao PDR. Malaria J., 10: 1-14.

Kolawole, O.M., O.A. Mokuolu, Y.A. Olukosi and T.O. Oloyede, 2016. Populations genomic diversity of Plasmodium falciparum in malaria patients attending Okelele Health Cendtre, Okelele, Ilorin, Kwara Stete, Nigeria. Afrika Health Sciences, 16: 704-711.

Muhammed, H., T. Mindaye, M. Belayneh, M. Kassa and A. Assefa, 2015. Genetic diversity of Plasmodium falciparum isolates based on MSP-1 and MSP-2 genes from Kolla-Shele area, Arbaminch Zuria District, southwest Ethiopia. Malaria J., 14: 1-7.

Nurwidayati, A., 2010. Article review: Response of antibodies to Plasmodium falciparum merozoite protein in determining malaria transmission. J. Vektor Penyakit, 4: 17-25.

Oyebola, M.K., E.T. Idowu, Y.A. Oluka, B.A. Iwalokun and C.O. Agomo et al., 2014. Genetic diversity and complexity of Plasmodium falciparum infections in Lagos. Nigeria, 4: 587-591.

Papua, D.K.P., 2017. The health profile of the Papua province in 2016. pp: 13-15.

Permenkes Malaria, 2009. Health Ministry Decree of Republic of Indonesia No 293/MENKES/SK/IV/2009. 28 April 2009 Concerning the Elimination of Malaria in Indonesia. Director General of P2PL, Department of Health.

Ricio, L.R.P., D.S.P. Silva., J.C.L. Junior, M. Theisen and F. Santos et al., 2013. Genetic polymorphism in the glutamate-rich protein of Plasmodium falciparum field isolates from a malaria-endemic area of Brazil. Mem. Isnt. Oswaldo Cruz, Rio de Janeiro, 108: 523-528.

Some, A.F., T. Baziè, I. Zongo, S. Yerbanga and F. Nikièma et al., 2018. Plasmodium falciparum msp 1 and $m s p 2$ genetic diversity and allele frequencies in parasites isolated from symptomatic malaria patients in Bobo-Diolasso, Burkina Faso. Parasites Vector, 11: 323 .

Sorontou, Y. and A. Pakpahan, 2015. Genetic diversity in MSP-1 gene of Plasmodium falciparum and its association with malaria severity, parasites density and host factor of asymptomatic and symptomatic patients in Papua, Indonesia. Int. J. Medical Science Public Health, 4: 1584-1593.

WHO, 2007. Methods and Techniques for Clinical Trial on Antimalarial Drug Efficacy: Genotyping to Identify Parasite Population. Amsterdam, The Netherlands, pp: 13-16. ISBN: 978924159630 